\title{
Impact of a spruce budworm outbreak in balsam fir and subsequent stand development over a 40-year period ${ }^{1}$
}

\author{
by David A. MacLean ${ }^{2}$ and Allison R. Andersen ${ }^{3}$
}

\begin{abstract}
Nine 0.04-ha plots were established in 1956 (age 35 years) in a balsam fir (Abies balsamea [L.] Mill.) stand in northwestern New Brunswick, Canada to determine the impact of an uncontrolled spruce budworm (Choristoneura fumiferana [Clem.]) outbreak on stand development. The plots were measured annually from 1956 to 1961 and at five-year intervals from 1965 to 1995. Moderate to severe defoliation occurred from 1951 to 1957 and again in 1975 to 1977, 1981, and 1986 to 1988. Budworm-caused mortality from 1956 to 1961 (age 35 to 40 years) varied considerably among plots, reducing volume by 35 to $113 \mathrm{~m}^{3} / \mathrm{ha}(34 \%-84 \%)$, and resulting in a wide range of post-outbreak plot densities. Plots were grouped into three post-budworm outbreak (1965, age 45 years) basal area classes, of $\leq 20 \mathrm{~m}^{2} / \mathrm{ha}, 21$ to $27 \mathrm{~m}^{2} / \mathrm{ha}$, and $\geq 28 \mathrm{~m}^{2} / \mathrm{ha}$, to examine stand recovery. Recovery of volume up to age 60 years ranged from 72 to $132 \mathrm{~m}^{3} / \mathrm{ha}$, in the lowest to highest basal area classes, respectively. From age 60 to 75 years, five plots declined in volume due to the onset of stand break-up and four plots increased in volume. By age 60 years, survivor growth was greatest in the high basal area plots, ranging from 6.2 to $9.0 \mathrm{~m}^{3} / \mathrm{ha} / \mathrm{yr}$ in seven plots, versus 2.6 to $3.2 \mathrm{~m}^{3} / \mathrm{ha} / \mathrm{yr}$ in two low basal area plots. From age 60 to 75 years, survivor growth averaged only 2.8 to $5.2 \mathrm{~m}^{3} / \mathrm{ha} / \mathrm{yr}$, and the stand exhibited major decline, with $63 \%, 74 \%$, and $78 \%$ mortality of fir $\leq 15 \mathrm{~cm} \mathrm{DBH}$ in the low to high basal area plots, respectively. Budworm-caused "thinning" in the 1950s largely determined subsequent stand development and the rate of stand break-up 25 to 35 years later. The timing and rate of natural stand decline was strongly influenced by post-outbreak stand density.
\end{abstract}

Key words: budworm-caused mortality, stand structure, stand development, growth, mortality, stand density

\section{RÉSUMÉ}

Neuf parcelles de 0,04 ha ont été mises en place en 1956 dans un peuplement de sapin baumier (Abies balsamea [L.] Mill.) (âgé de 35 ans) situé dans le nord-ouest du Nouveau-Brunswick au Canada, afin de déterminer les effets d'une épidémie non contrôlée de tordeuse des bourgeons d'épinette (Choristoneura fumiferana [Clem.]) sur le développement du peuplement. Les parcelles ont été mesurées annuellement de 1956 à 1961, puis à tous les cinq ans de 1965 à 1995 . Des défoliations classées de modérées à sévères ont eu lieu de 1951 à 1957 et à nouveau de 1975 à 1977, en 1981 et de 1986 à 1988. La tordeuse a entraîné de la mortalité de 1956 à 1961 (entre l'âge de 35 et 40 ans du peuplement) à des niveaux très différents entre les parcelles, ce qui a réduit le volume de 35 à $113 \mathrm{~m}^{3} / \mathrm{ha}(34 \%-84 \%)$ et a créé une grande diversité de densité dans les parcelles après l'épidémie. Les parcelles ont été regroupées en trois classes de surface terrière post épidémie de tordeuse (1965, 45 ans), soit $\leq 20 \mathrm{~m}^{2} /$ ha, de 21 à $27 \mathrm{~m}^{2} /$ ha et $\geq 28 \mathrm{~m}^{2} /$ ha, afin d'étudier l'évolution du peuplement. Le rattrapage en terme de volume à l'âge de 60 ans variait de 72 à $132 \mathrm{~m}^{3} /$ ha, de la classe la plus petite à la plus importante de surface terrière respectivement. Entre 60 et 75 ans, cinq parcelles ont vu leur volume diminuer suite à un bouleversement dans le peuplement et quatre parcelles ont vu leur volume augmenter. À 60 ans, la croissance des survivants était la plus forte dans les parcelles ayant la plus importante surface terrière, variant de 6,2 à $9,0 \mathrm{~m}^{3} / \mathrm{ha} / \mathrm{an}$ pour les sept parcelles, comparativement à 2,6 à $3,2 \mathrm{~m}^{3} / \mathrm{ha} /$ an pour les deux parcelles ayant une petite surface terrière. Entre 60 et 75 ans, la croissance des survivants était en moyenne de seulement 2,8 à 5,2 $\mathrm{m}^{3} / \mathrm{ha} / \mathrm{an}$ et le peuplement démontrait un déclin important avec une mortalité de $63 \%$, de $74 \%$ et de $78 \%$ des sapins ayant un $\mathrm{dhp} \leq 15 \mathrm{~cm}$ dans les parcelles de petite à forte surface terrière respectivement. L'« éclaircie » provoqué par la tordeuse dans les années 1950 a grandement influencé le développement du peuplement et son taux de bouleversement, 25 à 35 ans plus tard. Le moment et le niveau de déclin naturel du peuplement ont été influencés de façon importante par la densité post-épidémie du peuplement.

Mots clés : mortalité provoquée par la tordeuse, structure du peuplement, développement du peuplement, croissance, mortalité, densité du peuplement

\footnotetext{
${ }^{1}$ Paper presented in "Looking to the Past to Manage the Future. CFS Presents: Green River Revisited." SYLVICON 2007 Conference, February 14, 2007, Fredericton, New Brunswick.

${ }^{2}$ Dean, Faculty of Forestry and Environmental Management, University of New Brunswick, P.O. Box 44555, Fredericton, New Brunswick E3B 5A3. E-mail: macleand@unb.ca

${ }^{3}$ Canadian Forest Products Ltd., 5162 Northwood Pulpmill Rd., Prince George, British Columbia V2L 4W2
} 


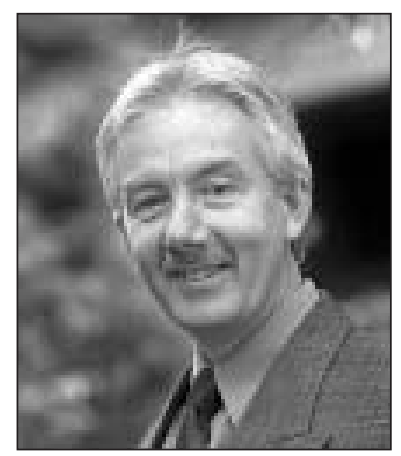

David A. MacLean

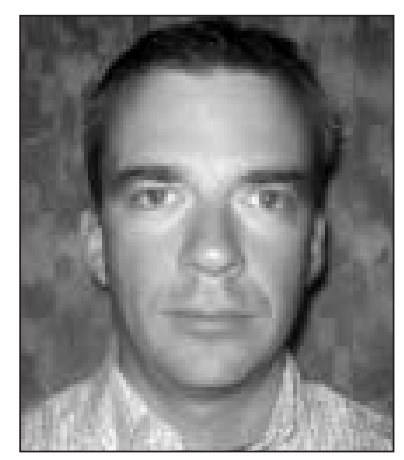

Allison R. Andersen

\section{Introduction}

Understanding and predicting stand development and its interaction with disturbance and silviculture are a key component of forest management. Long-term permanent plots are the best means of determining stand development patterns, but such data are relatively rare because of cost, and difficulty of maintaining continuity of measurements over long periods. This paper presents 40 years (1956 to 1995) of development of balsam fir (Abies balsamea [L.] Mill.) in New Brunswick, Canada, during and following two spruce budworm (Choristoneura fumiferana [Clem.]) outbreaks. This is the only long-term study of budworm impact and post-outbreak recovery, and one of few to evaluate stand development over four decades (age 35 to 75 years).

Spruce budworm outbreaks and harvesting have been two main factors influencing structure and function of balsam fir and spruce (Picea spp.) stands in eastern Canada (MacLean 1985, 1990). Budworm outbreaks killed an estimated 55 million $\mathrm{m}^{3}$ of timber in eastern Canada from 1910 into the 1920s (Swaine and Craighead 1924), 8.3 million $\mathrm{m}^{3}$ in Maine during 1909 to 1919 (McLintock 1955), and about 44 million $\mathrm{m}^{3}$ /year in Canada from 1977 to 1981 (Sterner and Davidson 1982). Major outbreak periods began about 1910, in the 1940s, and 1970s in eastern North America (Kettela 1983). Outbreaks not only resulted in tree mortality and timber losses, but also altered age-class distribution and species composition of forests over large areas. Spruce budworm outbreaks in eastern Canada reached a maximum extent of 55 million hectares in 1975 (Kettela 1983).

A severe spruce budworm outbreak occurred in the 1950s in northwestern New Brunswick, Canada. In 1956, 10 plots were established in a 35-year-old balsam fir stand and measured annually until 1961 (Baskerville 1960), and every five years from 1965 to 1995 . Baskerville and MacLean (1979) described patterns of mortality caused by budworm defoliation and subsequent recovery of the stand up to 1975 . Development encompassing a second budworm outbreak and onset of stand decline, until 1995, is presented in this paper.

Moderate to severe ( $>30 \%$ of current-year foliage) budworm defoliation occurred every year from 1951 to 1957 in the study stand (Morris 1963, Baskerville and MacLean 1979). Recovery of surviving balsam fir crowns after the collapse of the budworm population was rapid, but total height of trees in budworm-damaged stands remained $3 \mathrm{~m}$ to $4 \mathrm{~m}$ less than in undamaged stands as a result of top-killing
(Baskerville and MacLean 1979). Post-outbreak diameter increment recovered rapidly and was greatest in plots with the highest mortality, followed by those with average mortality, light mortality, and undamaged areas (Baskerville and MacLean 1979). However, the increased growth rate of individual trees was insufficient to offset volume loss to mortality, and by 1975 , only two out of ten plots had greater total volume per hectare than in 1956, due to low stocking. Plots with the lowest mortality recovered or were close to recovery of pre-outbreak total volume 15 years (1975) after the end of the outbreak.

A second budworm outbreak began in the early 1970s, but this time the stand was included in the operational budworm insecticide spray program. Aerial survey data indicated that moderate to severe defoliation occurred in the stand in 1975 to 1977,1981 , and 1986 to 1988 . By 1995, 35 years after the initial budworm population decline, the stand had reached maturity, which occurs from 70 to 80 years of age for balsam fir at this location. Balsam fir is a relatively short-lived species, with natural stand decline beginning at age 70 to 90 years (Bakuzis and Hansen 1965, Porter et al. 2001). Factors influencing rate of decline are not well understood, but the open stand structure is likely a factor in the present case. Declining growth after even-aged stands reach some limit appears to be universal, but the timing and magnitude vary (Ryan et al. 1997). The standard textbook explanation is that growth decline results from increased respiration, as the fraction of assimilates available for wood production declines as woody biomass and respiration of the living cells increase; however, Ryan et al. (1997) could find no support for this explanation in direct and indirect tests. Taylor and MacLean (2005) noted that stand decline is extensive in older fir-spruce in New Brunswick, affecting one-third of 585 New Brunswick Department of Natural Resources permanent sample plots. The driving mechanism of declining volume production was increased mortality rates, which played a bigger role than documented in other studies, while decreased growth of residual surviving trees played a relatively minor role, and ingrowth was negligible (Taylor and MacLean 2005).

The long-term plots in this study offer an opportunity to determine both patterns of development of stands impacted by a natural disturbance and influence of stand structure upon rate of decline. The objectives of this paper are: 1) to determine patterns of stand development from 1956 to 1995 for nine plots in New Brunswick, which had sustained severe defoliation during the period 1951 to $1957 ; 2$ ) to compare development among plots with different levels of budwormcaused mortality, and thereby, varying post-budworm stand structure; and 3) to determine extent of stand break-up and volume decline by 1995 (age 75 years), and degree to which decline was related to post-budworm (1965, age 45) stand structure.

\section{Materials and Methods \\ Stand description}

Stands in the study area originated as advanced regeneration released after spruce budworm killed mature overstory during an outbreak from 1913 to 1919 (Baskerville and MacLean 1979). Stands were even-aged, on well-drained sites of silty-clay 
loams and had sustained little disturbance from release up to the time of the budworm outbreak in the early 1950s. Some large spruce that survived the 1913 to 1919 outbreak were harvested for logs during winter in the 1930s and 1940s, and transported from the woods using horses, causing minimal disturbance to the residual stand (Baskerville and MacLean 1979).

The permanent sample plots analysed in this study were established as part of a large cooperative program for entomological and forest research, which took place in the Green River Watershed in northwestern New Brunswick, Canada in the early 1950s (Morris 1963, Baskerville and MacLean 1979). A 5400-ha tract of land was set aside near the centre of a spruce budworm outbreak, and was not protected (sprayed with insecticide) nor logged, so that the effects of an uncontrolled outbreak could be studied.

\section{Plot establishment and measurement}

In 1956, ten circular 0.04-ha plots were randomly located in an 8-ha immature balsam fir stand in northwestern New Brunswick known as K-2 (see Morris 1963 Fig. 1.1 for stand location). One of the plots was cut between 1975 and 1980; data presented in this paper are based on the nine remaining plots. Every tree was numbered and its location in the plot was mapped. Plots were measured annually from 1956 to 1961, in 1965, and then every five years thereafter up to 1995. At establishment, individual tree data were collected indicating diameter at breast height (DBH), crown class (dominant, codominant, intermediate, suppressed), and budworm defoliation, rated using a visual assessment of proportion of current foliage remaining after insect feeding (scale of light $0 \%-25 \%$, moderate 26\%-75\%, and severe 76\%-100\%). From 1957 to 1961 , defoliation and mortality of each tree were assessed each year. Trees were recorded as being dead only when the inner bark was dry and discoloured on two sides of the stem. Spruce budworm defoliation (mean \% of current-year foliage removed) for the stand each year from 1948 to 1960 was $0,0,20,45,91,98,98,34,92,48,2,2$, and 2\% (Morris 1963, Baskerville and MacLean 1979). Every five years from 1965 to $1995, \mathrm{DBH}$ and mortality were assessed, except in 1975, when only five of the plots (Nos. 71, 73, 77, 78, and 79) were remeasured. Heights were recorded for a sample of fir and spruce in 1956, 1965, and 1970. In 1980, 1985, 1990, and 1995 heights of all trees in each plot were measured.

Spruce budworm populations increased to outbreak levels again in the 1970s. At that time, the area was part of the operational budworm spray program, using insecticides to prevent defoliation and limit tree mortality (Kettela 1975, Webb and Irving 1983). No ground-based defoliation estimates for plots are available for that period, but data from annual aerial defoliation surveys (MacLean and MacKinnon 1996) indicated that defoliation was severe $(71 \%-100 \%)$ in 1975 to 1977 , moderate $(31 \%-70 \%)$ in 1981 , severe in 1986 to 1988 , and nil to light $(0 \%-30 \%)$ in all other years from 1961 to 1995. The multi-year defoliation periods are consistent with forest protection policy, which specified that stands had to sustain moderate to severe defoliation for at least two successive years before they became eligible for insecticide spraying. This policy was aimed at preventing tree mortality rather than growth reduction, and was generally effective (Kettela 1975, Webb and Irving 1983, MacLean et al. 1984).

\section{Height and volume calculation}

Separate height-diameter relationships were constructed for balsam fir and for black spruce (Picea mariana [Mill.] BSP) from 1956 to 1975 and from 1980 to 1995, and for white birch (Betula papyrifera Marsh.) from 1980 to 1995. Linear and quadratic regression analyses were applied, and in all cases, quadratic regression equations better fit the relationships. Height-DBH regression equations, by species, were used to calculate heights from 1956 to 1975 for each tree in each plot. From 1980 to 1995, equations were used to calculate only a few non-measured heights. Total volume per tree in each period was calculated using height and $\mathrm{DBH}$ and volume equations for each species from Honer et al. (1983).

Total volume per plot and periodic mortality $\left(\mathrm{m}^{3} / \mathrm{ha}\right)$ were calculated by species at the end of each five-year period. Using these data, the survivor growth $(G)$ of trees in each plot was also calculated as $\mathrm{m}^{3} /$ ha per period:

$$
\text { [1] } \quad G=\left(V_{t+1}-V_{t}\right)+M
$$

where $V_{t+1}$ is the total volume at the end of the period, $V_{t}$ is total volume at the beginning of the period, and $M$ is the periodic mortality ( $\mathrm{m}^{3} / \mathrm{ha}$ ) from $t$ to $t+1$.

Largely as a result of uneven losses to budworm defoliation, there was wide variation in the post-outbreak species composition and stand density of plots in 1965, with basal area ranging from 13.6 to $41.6 \mathrm{~m}^{2} / \mathrm{ha}$. We hypothesized that the post-outbreak basal area would be a strong indicator of subsequent development. Therefore, for presentation of trends of volume, mortality, and survivor growth from 1965 to 1995 , we grouped plots into three relative density classes with three plots each, based on the 1965 basal area: high ( $\geq 28$ $\mathrm{m}^{2}$ /ha, plots 74-76), medium (21-27 $\mathrm{m}^{2} /$ ha, plots 71,73 , and 78 ), and low ( $\leq 20 \mathrm{~m}^{2} /$ ha, plots 72,77 , and 79).

\section{Results and Discussion Height-DBH relationships}

Height-DBH relationships for fir and spruce differed substantially between the budworm outbreak and post-outbreak period (1956 to 1970) versus later years after stand recovery and growth (1980 to 1995) (Fig. 1). Moderate to severe budworm defoliation results in the cessation of height growth, as the leader is repeatedly destroyed for several years, and also often results in top killing (Ostaff and MacLean 1989). Top killing resulted in fir trees in the study being $3 \mathrm{~m}$ to $4 \mathrm{~m}$ shorter at the end of the outbreak than comparable trees in undamaged stands (Baskerville and MacLean 1979). The seven successive years of moderate-severe defoliation from 1951 to 1957 had a much greater effect than the two threeyear periods from 1975 to 1977 and 1986 to 1988, when insecticide spraying limited any more than three years of severe defoliation, and permitted some foliage recovery. As expected, the shape of the fir height-DBH relationship from 1956 to 1970, influenced by the severe outbreak (Fig. 1A) differed from that of 1980 to 1995 (Fig. 1B). Top-killing resulted in an unusual "concave" curve shape in Fig. 1A. Height of defoliated trees with DBH of $10 \mathrm{~cm}$ and $20 \mathrm{~cm}$ was predicted, based on 1956 to 1970 relationships, to be $7.8 \mathrm{~m}$ and $8.0 \mathrm{~m}$, whereas similar-sized (but 25 years older) trees in 1980 to 1995 were $8.9 \mathrm{~m}$ and $15.0 \mathrm{~m}$ tall. These differences have obvious growth 


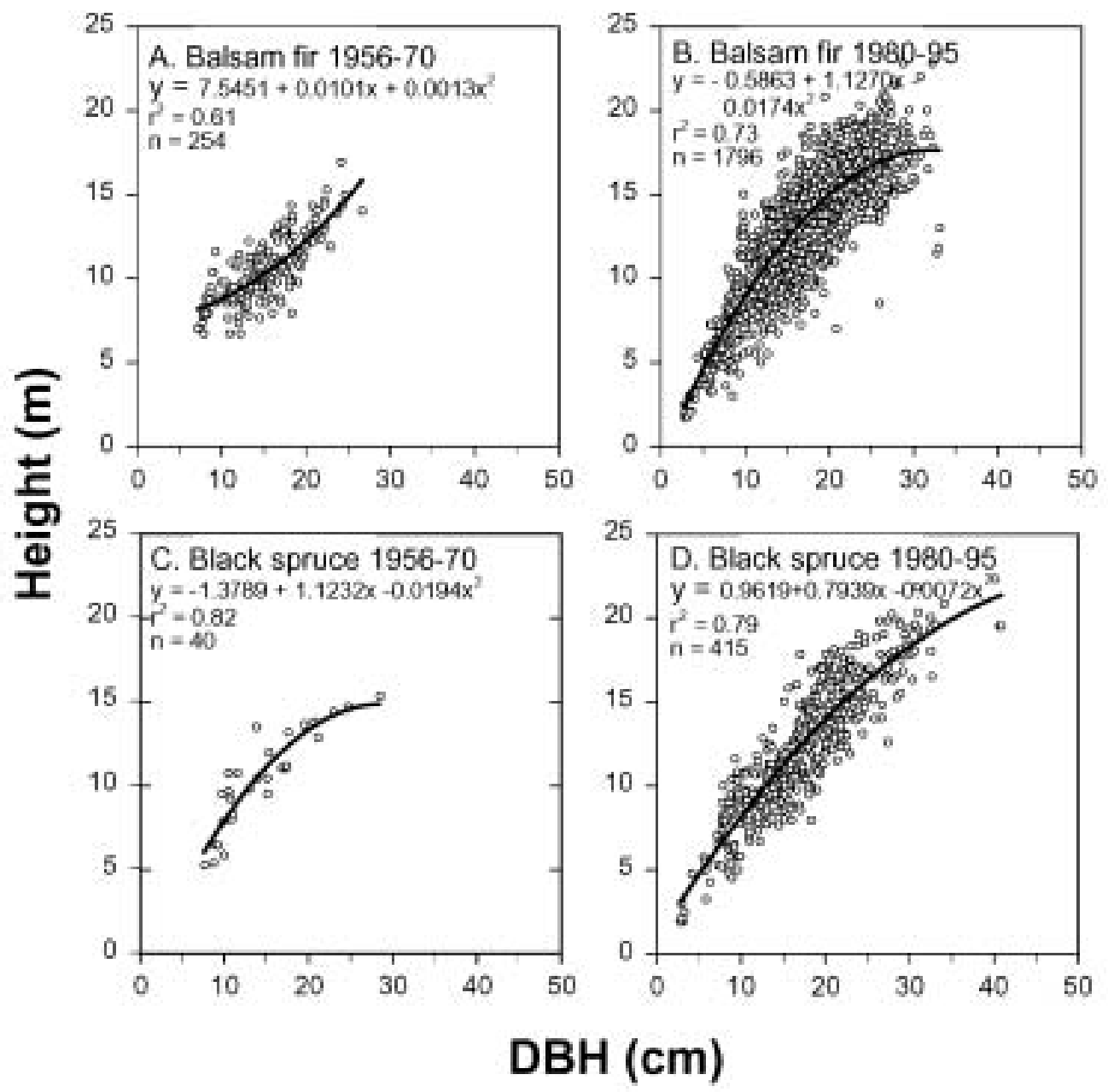

Fig. 1. Height to diameter relationships for balsam fir and black spruce during two different periods (1956 to 1970, 1980 to 1995) in nine balsam fir plots in northwestern New Brunswick. Spruce budworm defoliation from 1950 to 1957 influenced relationships in A. and C.

and yield implications, but also suggest strong effects of defoliation on site index and height-DBH relationships.

In contrast, black spruce height-DBH relationships were more similar between 1956 and 1970 versus 1980 to 1995 (Fig. 1C, D), except that height of larger trees levelled off from 1956 to 1970 . Defoliated (1956 to 1970) black spruce with $\mathrm{DBH}$ of $10 \mathrm{~cm}$ and $20 \mathrm{~cm}$ were predicted to be $7.9 \mathrm{~m}$ and $12.3 \mathrm{~m}$ tall, whereas similar trees from 1980 to 1995 were $8.2 \mathrm{~m}$ and $13.9 \mathrm{~m}$ tall. Based on these height-DBH relationships, defoliated balsam fir of $10 \mathrm{~cm}, 20 \mathrm{~cm}$, and 30 $\mathrm{cm} \mathrm{DBH}$ were $12 \%, 47 \%$, and $49 \%$ shorter than undefoliated trees and black spruce were $4 \%, 11 \%$, and $18 \%$ shorter. This reflects the preference of budworm for feeding on balsam fir and the ability of spruce to withstand more defoliation.

These height reductions substantially reduce growing stock available to produce volume increment. Reduction in $\mathrm{DBH}$ growth is linearly related to cumulative defoliation for both fir and black spruce (Erdle and MacLean 1999), and overall volume growth is reduced by up to $90 \%$ during spruce budworm outbreaks (Ostaff and MacLean 1995, MacLean et al. 1996).

\section{Stand characteristics and species composition}

Densities of the nine plots in 1956 ranged from less than 5000 stems/ha to more than 9000 stems/ha (Table 1). Theses plots were typical of immature fir stands that were extensive in the area at the time. Species composition was at least 65\% balsam fir, with $2 \%$ to $20 \%$ birch and spruce. From 1956 to 1965 , total volume decreased by an average of $60 \mathrm{~m}^{3} /$ ha because of budworm-caused tree mortality (Table 1). Average density decreased from 6490 stems/ha in 1956 to 2485 stems/ha in 1965. Over the next 30 years, mortality continued as a part of stand development, resulting in an average density of 980 stems/ha in 1995.

Budworm-caused tree mortality varied considerably among plots, exceeding the variation in initial stand characteristics (Baskerville and MacLean 1979). Plots within $50 \mathrm{~m}$ of each other showed the extremes of greatest $(80 \%)$ to least (18\%) fir $\mathrm{m}^{3} /$ ha mortality. A wide range of budworm-caused mortality is typical for immature fir, although mortality averages about 40\% (MacLean 1980). Mortality occurred in small-scale patches that became larger as the outbreak progressed, leaving live trees in a clumped spatial distribution (Baskerville and MacLean 1979). 
Table 1. Stand characteristics of nine 0.04-ha plots in a balsam fir stand in northern New Brunswick in 1956, 1965 , and 1995. The stand underwent a severe spruce budworm outbreak from 1951 to 1957; stand age was 35 years in 1956.

\begin{tabular}{|c|c|c|c|c|c|c|c|c|c|c|c|c|}
\hline \multirow[b]{2}{*}{ Plot } & \multicolumn{3}{|c|}{$\begin{array}{l}\text { Total volume } \\
\left(\mathrm{m}^{3} / \mathrm{ha}\right)\end{array}$} & \multicolumn{3}{|c|}{$\begin{array}{l}\text { Stand density } \\
\text { (stems/ha) }\end{array}$} & \multicolumn{3}{|c|}{$\begin{array}{c}\text { Mean DBH } \\
(\mathrm{cm})\end{array}$} & \multicolumn{3}{|c|}{$\begin{array}{l}\text { Basal area } \\
\left(\mathrm{m}^{3} / \mathrm{ha}\right)\end{array}$} \\
\hline & 1956 & 1965 & 1995 & 1956 & 1965 & 1995 & 1956 & 1965 & 1995 & 1956 & 1965 & 1995 \\
\hline 71 & 171 & 108 & 128 & 6150 & 2372 & 650 & 6.9 & 8.7 & 17.9 & 36.5 & 22.1 & 27.5 \\
\hline 72 & 169 & 71 & 163 & 6130 & 1582 & 1050 & 9.9 & 8.7 & 16.1 & 35.4 & 14.6 & 35.7 \\
\hline 73 & 200 & 123 & 254 & 9290 & 2668 & 1350 & 7.1 & 9.0 & 17.0 & 44.4 & 24.7 & 44.9 \\
\hline 74 & 169 & 166 & 240 & 5260 & 3040 & 1000 & 6.9 & 9.6 & 19.1 & 34.8 & 32.6 & 35.1 \\
\hline 75 & 189 & 211 & 296 & 7020 & 4176 & 1125 & 8.2 & 8.8 & 18.9 & 39.4 & 41.6 & 39.3 \\
\hline 76 & 197 & 149 & 231 & 7020 & 2619 & 1050 & 8.2 & 9.5 & 19.0 & 41.7 & 28.1 & 42.0 \\
\hline 77 & 208 & 112 & 172 & 4700 & 1606 & 750 & 9.0 & 10.3 & 19.1 & 40.6 & 20.4 & 40.9 \\
\hline 78 & 211 & 140 & 222 & 7330 & 2446 & 1150 & 8.0 & 10.2 & 17.1 & 44.6 & 27.8 & 45.2 \\
\hline 79 & 157 & 64 & 150 & 5540 & 1853 & 725 & 7.1 & 9.6 & 18.3 & 33.5 & 13.6 & 33.7 \\
\hline Mean & 187 & 127 & 206 & 6490 & 2485 & 983 & 7.9 & 9.4 & 18.1 & 39.0 & 27.3 & 38.3 \\
\hline
\end{tabular}

Table 2. Stand species composition of nine plots in a balsam fir stand in northern New Brunswick in 1956, 1965, and 1995.

\begin{tabular}{|c|c|c|c|c|c|c|c|c|c|c|c|c|c|c|c|c|c|c|}
\hline \multirow[b]{3}{*}{ Plot } & \multicolumn{9}{|c|}{$\%$ Stems/ha } & \multicolumn{9}{|c|}{$\%$ Basal area } \\
\hline & \multicolumn{3}{|c|}{ Balsam fir } & \multicolumn{3}{|c|}{ Spruce } & \multicolumn{3}{|c|}{ Birch } & \multicolumn{3}{|c|}{ Balsam fir } & \multicolumn{3}{|c|}{ Spruce } & \multicolumn{3}{|c|}{ Birch } \\
\hline & 1956 & 1965 & 1995 & 1956 & 1965 & 1995 & 1956 & 1965 & 1995 & 1956 & 1965 & 1995 & 1956 & 1965 & 1995 & 1956 & 1965 & 1995 \\
\hline 71 & 72 & 45 & 27 & 20 & 37 & 38 & 8 & 18 & 35 & 83 & 60 & 45 & 16 & 35 & 44 & 1 & 5 & 11 \\
\hline 72 & 85 & 44 & 45 & 2 & 6 & 5 & 13 & 48 & 50 & 90 & 53 & 53 & 6 & 16 & 11 & 5 & 31 & 36 \\
\hline 73 & 86 & 61 & 61 & 7 & 18 & 17 & 7 & 22 & 22 & 89 & 70 & 69 & 9 & 23 & 26 & 2 & 7 & 5 \\
\hline 74 & 92 & 89 & 90 & 5 & 8 & 5 & 3 & 5 & 5 & 96 & 63 & 92 & 3 & 31 & 7 & 1 & 6 & 1 \\
\hline 75 & 68 & 55 & 51 & 12 & 17 & 20 & 20 & 27 & 29 & 74 & 67 & 60 & 18 & 23 & 30 & 8 & 10 & 10 \\
\hline 76 & 87 & 75 & 76 & 6 & 11 & 9 & 7 & 14 & 16 & 90 & 79 & 78 & 8 & 14 & 14 & 2 & 7 & 8 \\
\hline 77 & 80 & 52 & 43 & 9 & 22 & 23 & 11 & 25 & 33 & 88 & 71 & 58 & 6 & 14 & 22 & 6 & 15 & 20 \\
\hline 78 & 87 & 62 & 57 & 7 & 20 & 17 & 6 & 18 & 26 & 88 & 70 & 60 & 10 & 24 & 30 & 2 & 6 & 10 \\
\hline 79 & 93 & 84 & 79 & 4 & 12 & 14 & 2 & 4 & 7 & 95 & 82 & 82 & 4 & 14 & 15 & 1 & 4 & 3 \\
\hline Mean & 83 & 63 & 59 & 8 & 17 & 16 & 9 & 20 & 25 & 88 & 68 & 66 & 9 & 22 & 22 & 3 & 10 & 12 \\
\hline
\end{tabular}

Mean DBH averaged $7.9 \mathrm{~cm}, 9.4 \mathrm{~cm}$, and $18.1 \mathrm{~cm}$ in 1956, 1965 , and 1995, respectively (Table 1). The $1.5-\mathrm{cm}$ increase in mean DBH from 1956 to 1965 reflected alteration of the DBH distribution caused by mortality, as well as the beginning of stand recovery. From 1965 to 1995, all plots showed increases in mean DBH, ranging from $6.9 \mathrm{~cm}$ to $10.1 \mathrm{~cm}$. Basal area averaged $39.0,27.3$, and $38.3 \mathrm{~m}^{2} /$ ha in 1956,1965 , and 1995 , respectively (Table 1 ). Mortality resulted in basal area decreasing by 2.2 to $20.8 \mathrm{~m}^{2} /$ ha from 1956 to 1965 in eight of the nine plots. With subsequent stand recovery, basal area increased by 5.4 to $20.5 \mathrm{~m}^{2} /$ ha by 1995 for seven plots, while one increased by $2.5 \mathrm{~m}^{2} / \mathrm{ha}$ and another plot decreased by $2.3 \mathrm{~m}^{2} / \mathrm{ha}$.

Although the plots were in a 5400-ha area that was not protected from defoliation, there was a wide range in the impact of defoliation, and therefore, in post-outbreak stand structure in the various plots. Mortality during the budworm outbreak substantially altered species composition, with $20 \%$ less fir (from $83 \%$ stems/ha in 1956 to $63 \%$ in 1965), and doubled spruce and birch content (Table 2). Species composition remained relatively constant over the next 30 years, averaging 59\% fir, 16\% spruce, and 25\% birch stems/ha (or $66 \%, 22 \%$, and $12 \%$ of basal area) in 1995 . On average, birch increased by $220 \%$ of stems/ha or $330 \%$ of basal area from
1956 to 1965, reflecting differences in shade tolerance and ability of birch to "capture" crown openings.

\section{Post-outbreak stand structure}

Stand structure and species composition in 1965 (Fig. 2), resulting from differing levels of budworm-caused mortality, largely determined patterns of recovery over the next three decades. There was a wide range of budworm-caused mortality from 1956 to 1965, from 2220 stems/ha to 6700 stems/ha (Fig. 2C). In general, plots with high budworm-caused fir mortality had higher birch content, up to 50\% and 30\% stems/ha in plots 72 and 75 (Fig. 2). Post-outbreak variability in species composition and density exceeded variability in the 1956 stand (Tables 1 and 2), and contributed to differential stand development three decades later.

\section{Volume development from 1956 to 1995}

Total volume

Fig. 3 presents the volume development pattern for the nine plots, from age 35 to 75 years (1956 to 1995). Budwormcaused mortality, and to a lesser extent, differences in initial stand density, determined differences among the plots at age 40 (Fig. 3A to C). Budworm-caused mortality (age 35 to 40) 

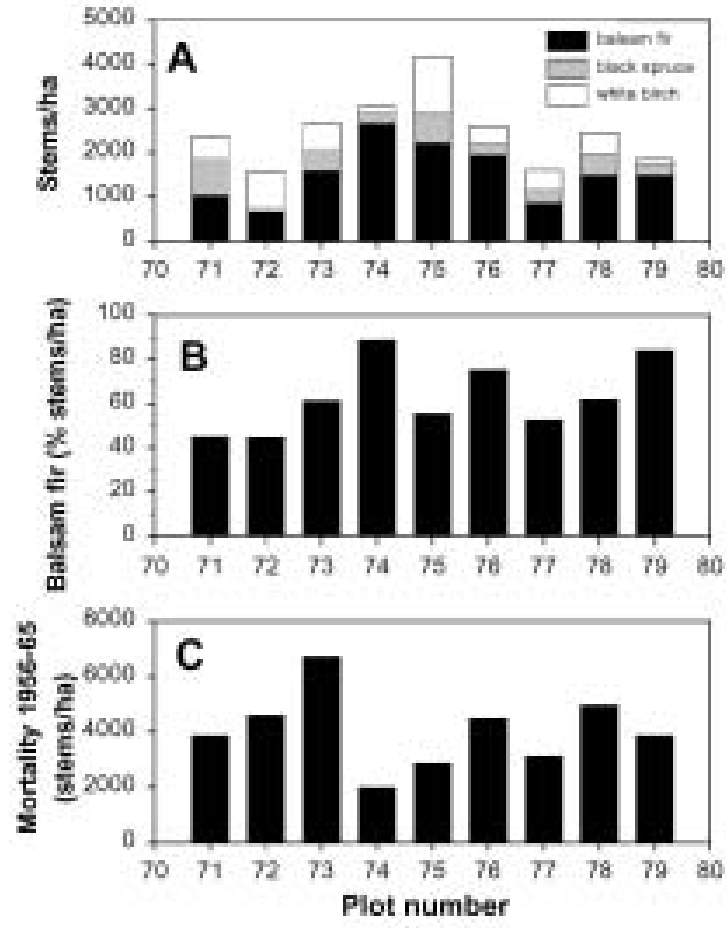

Fig. 2. (A) Stand density for all species and (B) \% balsam fir, in 1965, following the spruce budworm outbreak. (C) Budwormcaused mortality from 1956 to 1965.

averaged 35,88 , and $110 \mathrm{~m}^{3} /$ ha for high, medium, and low basal area classes, respectively. Living volume at the end of the budworm outbreak ranged from 34 to $80 \mathrm{~m}^{3} /$ ha in low basal area plots, 90 to $116 \mathrm{~m}^{3} /$ ha in medium basal area, and 96 to $165 \mathrm{~m}^{3} /$ ha in high basal area plots (Fig. 3). In comparison, total volume of both branches and stems totalled 97 to 155 $\mathrm{m}^{3} /$ ha in other 40 -year-old fir stands protected from defoliation by budworm (Baskerville 1965); stem volume comprised 89 to $146 \mathrm{~m}^{3} / \mathrm{ha}$.

From age 40 to 60 years, volume increased linearly, by averages of 129,107 , and $73 \mathrm{~m}^{3} /$ ha for high, medium, and low basal area classes. From age 60 to 75 , volume continued to increase in four plots but decreased in five plots. At age 75, firspruce volume ranged from 111 to $275 \mathrm{~m}^{3} /$ ha among the nine plots (Fig. 3). Plots 73 to 76 , and 78 (three high and two medium basal area plots) had total volumes greater than 200 $\mathrm{m}^{3}$ /ha and plots 71, 72, 77, 79 (three low and one medium basal area) were less than $150 \mathrm{~m}^{3} / \mathrm{ha}$ in 1995. In 1979, Baskerville and MacLean used a simple mensurational model to project development of the then 55-year-old plots to age 75 . Volumes predicted were less than $150 \mathrm{~m}^{3} /$ ha for plot 72 ; 150 to $300 \mathrm{~m}^{3} / \mathrm{ha}$ for plots $71,74,77$ to $79 ; 301$ to $350 \mathrm{~m}^{3} / \mathrm{ha}$ for plots 73, 75; and $410 \mathrm{~m}^{3} /$ ha for plot 76 . The highest total volume actually achieved by age 75 was $296 \mathrm{~m}^{3} / \mathrm{ha}$ in plot 75 (Fig. 3). Baskerville and MacLean (1979) did not anticipate the early onset of stand break-up in these plots, as shown by volume declines after age 60 .

\section{Mortality}

Patterns of mortality, in five-year periods from 1956 to 1995, showed high budworm-caused mortality from age 35 to 40

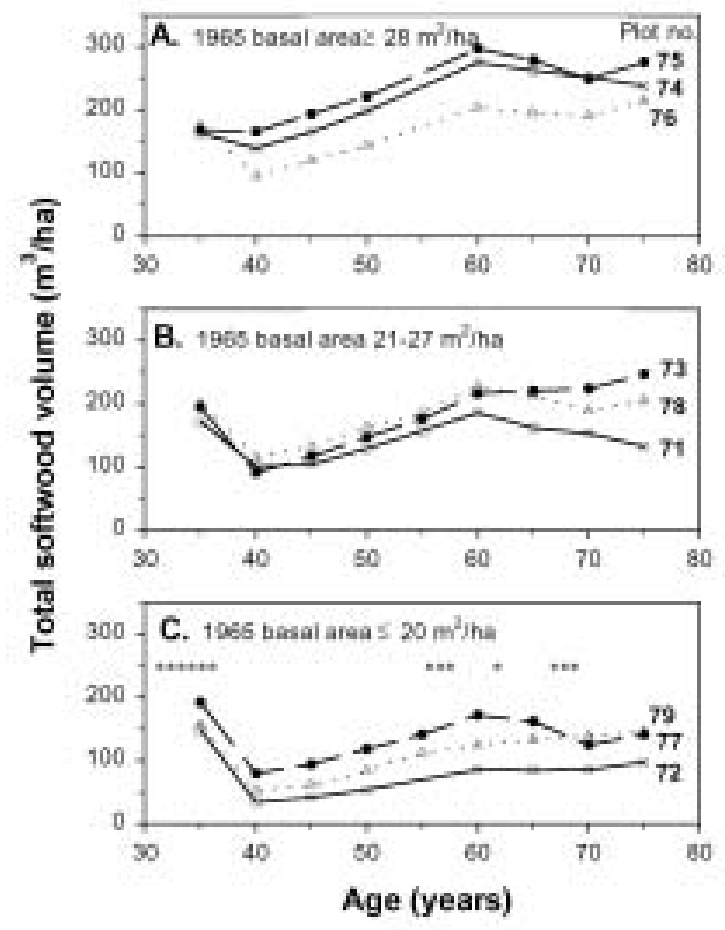

Fig. 3. Total softwood volume development from 1956 to 1995 for nine balsam fir plots grouped by post-budworm outbreak (age 45, 1965) basal area: (A) high ( $\geq 28 \mathrm{~m}^{2} / \mathrm{ha}$ ), (B) medium (21-27 $\mathrm{m}^{2} / \mathrm{ha}$ ), and (C) low $\left(\leq 20 \mathrm{~m}^{2} / \mathrm{ha}\right.$ ). Asterisks in $\mathrm{C}$ show years of moderate to severe defoliation.

(data are plotted at the end of each five-year period in Fig. 4), and little mortality from age 40 to 60 when open stands resulted in little competition. Mortality increased beyond age 60 as remaining fir trees reached maturity. Budworm-caused mortality from age 35 to 40 years ranged from 18.0 to 24.6 $\mathrm{m}^{3} / \mathrm{ha} / \mathrm{yr}$ among seven plots, but was only 5.4 to $8.0 \mathrm{~m}^{3} / \mathrm{ha} / \mathrm{yr}$ in plots 74 to 75 . From age 40 to 45 , mortality was 0.4 to 1.4 , 0.6 to 4.0 , and 0.4 to $1.2 \mathrm{~m}^{3} / \mathrm{ha} / \mathrm{yr}$ in high, medium and low basal area plots, respectively (Fig. 4). Baskerville and MacLean (1979) observed that from 1961 to 1965 , mortality was still being influenced by the budworm outbreak. Mortality was consistently low from age 50 to 60 , with a range of 0.1 to 0.4 $\mathrm{m}^{3} / \mathrm{ha} / \mathrm{yr}$ in all plots, except for high basal area plots 74 and 75 , which had mortality of 1.3 and $1.0 \mathrm{~m}^{3} / \mathrm{ha} / \mathrm{yr}$ from age 50 to 60 (Fig. 4A). From age 65 to 75, mortality increased in all three classes (Fig. 4). Total age-related mortality over 30 years from age 45 to 75 averaged $4.3 \mathrm{~m}^{3} / \mathrm{ha} / \mathrm{yr}$ in the low basal area plots, 7.4 in medium, and $9.4 \mathrm{~m}^{3} / \mathrm{ha} / \mathrm{yr}$ in high basal area plots. Therefore, lower budworm-caused mortality from age 35 to 40 resulted in a denser stand at age 45 , which then sustained higher mortality than more open plots with the onset of old age from 60 to 75 years (Fig. 4).

Aerial surveys indicated moderate-severe budworm defoliation in seven years from age 55 to 68 (1975 to 1988) (shown as asterisks in Fig. 4C). It usually takes at least four successive years of moderate to severe defoliation to cause tree mortality (MacLean 1980), and insecticide spraying apparently was effective in preventing this. Since it seems unlikely that defo- 

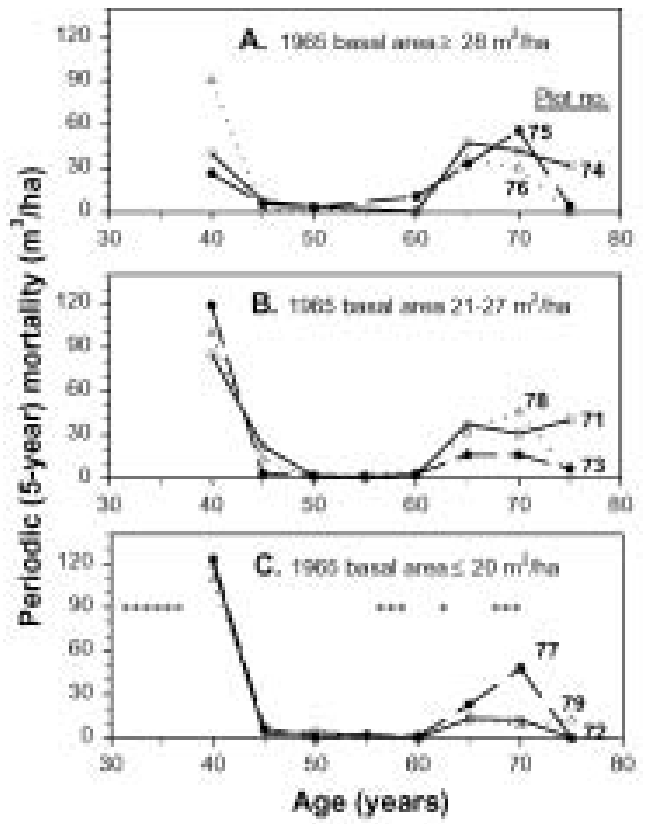

Fig. 4. Periodic (five-year) mortality of softwood from 1956 to 1995, in nine balsam fir plots in northwestern New Brunswick, grouped according to post-budworm outbreak (age 45) basal area. Values are plotted at the end of the five-year period; asterisks in $\mathrm{C}$ show years of moderate to severe defoliation.

liation would be greatest in the high basal area plots, second in the medium, and lowest in the low basal area plots, we attribute tree death after age 60 to the onset of old age, rather than to defoliation.

When mature balsam fir stands undergo an uncontrolled spruce budworm outbreak, tree mortality is consistently high, averaging $85 \%$, and with a typical range of $70 \%$ to $100 \%$ (MacLean 1980). Advanced balsam fir regeneration often increases in growth due to the opened canopy resulting from defoliation and tree mortality, resulting in a cyclical firreplacing-fir succession pattern, as observed both in northern New Brunswick (Baskerville 1975) and on Cape Breton Island, Nova Scotia (MacLean 1988). In the latter Nova Scotia case, budworm-caused mortality averaged $87 \%$ of fir and $27 \%$ of spruce (MacLean and Ostaff 1989), reducing live crown coverage from $77 \%$ to $10 \%$. Advanced fir regeneration at stocking of 67 to $100 \%$ then succeeded trees killed by budworm (MacLean 1988). Severe defoliation thus "cycles" mature stands to a regenerating condition, with advanced regeneration in time replacing the remaining overstory.

Severe budworm defoliation in immature balsam fir stands typically results in a "thinned" stand condition, with an open canopy at a lower density than before defoliation. Baskerville (1975) noted cycles in the continuous balsam fir forest in northwestern New Brunswick, in which budworm "silviculturally treats" stands by recycling mature or overmature stands to a regenerating condition. Budworm-caused mortality releases dense natural advance regeneration, which is then attacked by budworm in the next outbreak in 30 to 40 years, creating a thinning effect. This thinning allows these 30- to 40-year-old stands to reach a more favourable, open, mature condition for budworm attack, and the process starts again when the next outbreak cycle occurs. This sequence of forest events took place in New Brunswick with four different outbreaks beginning about 1875, 1912, 1949 (Baskerville 1975), and 1970 (Kettela 1983). While the subject stands were not protected in the 1951 to 1957 outbreak, the 1970s to 1980s outbreak was characterized by aggressive use of insecticides, which effectively limited budworm-caused tree mortality (Kettela 1975, Webb and Irving 1983, MacLean et al. 1984).

High spatial variability in budworm-caused mortality among plots was also observed in immature fir stands in Nova Scotia (MacLean and Piene 1995). Studies with detailed, individual-tree measures of defoliation have shown that tree mortality is strongly related to cumulative defoliation. MacLean and Piene (1995) determined that $80 \%$ to $90 \%$ of the trees that died during the outbreak had more than $75 \%$ cumulative defoliation, while Erdle and MacLean (1999) demonstrated that fir and spruce survival declined as a function of both cumulative defoliation and stand age.

\section{Survivor growth}

During and following an outbreak, net stand volume increases by the amount that growth of surviving trees exceeds mortality in a given period. Overall, from age 40 to 60 , survivor growth increased in all plots, with the magnitude generally greatest in the high basal area plots, intermediate in the medium basal area plots, and lowest in the low basal area plots. After the budworm outbreak, from age 45 to 50 , survivor growth averaged $6.8,7.0$, and $4.2 \mathrm{~m}^{3} / \mathrm{ha} / \mathrm{yr}$ in high, medium, and low basal area plots, respectively (Fig. 5). From age 55 to 60 , survivor growth was $8.8,8.2$, and $5.4 \mathrm{~m}^{3} / \mathrm{ha} / \mathrm{yr}$, respectively, but from age 60 to 75 it averaged only 5.2, 3.8, and $3.0 \mathrm{~m}^{3} / \mathrm{ha} / \mathrm{yr}$ for high, medium, and low basal area plots. This represented decreases of $41 \%, 54 \%$, and $44 \%$ in comparison with age 55 to 60 , when survivor growth reached a maximum for seven of the nine plots (numbers 72 to 78). The dramatic declines in survivor growth from age 60 to 65 evident in five plots (Fig. 5) generally coincided with increased mortality rates (Fig. 4). These reflect the onset of natural stand break-up for the balsam fir component. Although there may have been some cumulative effect of defoliation in the 1970s and 1980s, in general the observed decline did not coincide with years of defoliation.

It is well known that defoliation during a spruce budworm outbreak reduces growth rates. This is evident in the generally low growth rates from age 35 to 40, plotted at age 40 in Fig. 5. The first year of $80 \%$ to $100 \%$ defoliation of current foliage has been shown to cause up to a $20 \%$ reduction in growth (Piene 1980), and up to $50 \%$ growth reduction following similar defoliation for a second year. Overall volume loss caused by a budworm outbreak in immature and mature fir stands was estimated to be $62 \%$ and $81 \%$, respectively (Erdle and MacLean 1999). After an outbreak, if trees survive, growth rates do recover. Ostaff and MacLean (1995) noted that trees moderately to severely defoliated for three to five years responded by increasing the number of shoots by three to five times. Production of an average of six shoots per $\mathrm{cm}$ of branch length after severe defoliation allowed rapid recovery of growth rates. 

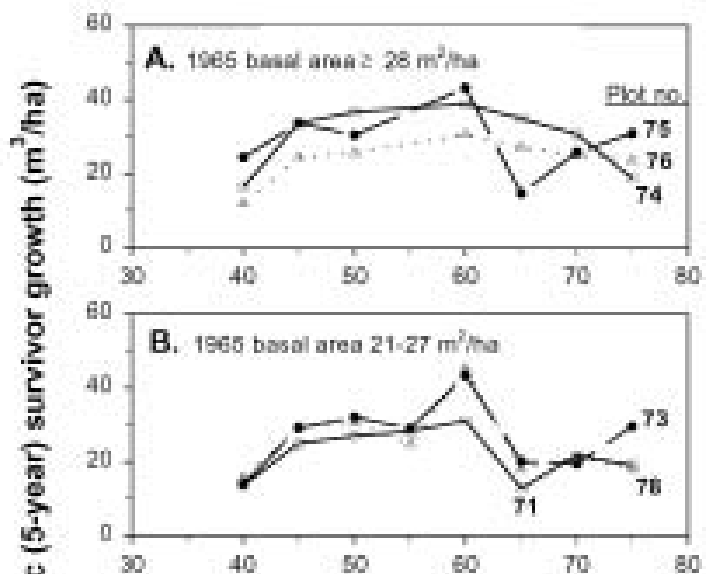

음

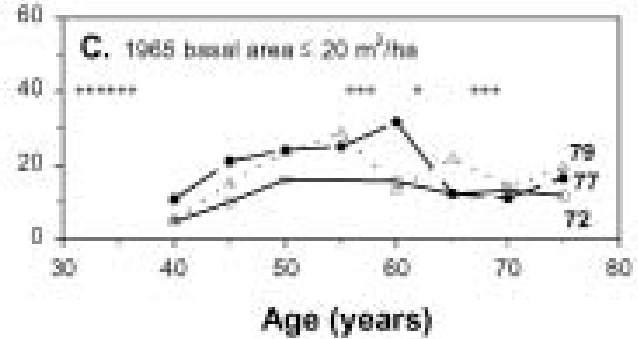

Fig. 5. Periodic survivor growth $\left(\mathrm{m}^{3} / \mathrm{ha}\right)$ for softwood species in nine balsam fir plots in northwestern New Brunswick from 1956 to 1995. The nine plots were grouped according to post-budworm outbreak lage 45) basal area. Asterisks in $C$ show years of moderate to severe defoliation.

\section{Stand break up}

The trends of generally decreasing survivor growth and increasing mortality from age 60 to 75 years (Figs. 4, 5) indicate that the stand had begun to decline and break up. To evaluate this further, the diameter distributions of trees that died over this period, and of remaining live trees at age 75 , were examined (Fig. 6). This clearly showed the heavy mortality that occurred, especially in the smaller $(\leq 15 \mathrm{~cm}) \mathrm{DBH}$ classes. On average, $63 \%, 74 \%$, and $78 \%$ of balsam fir $\leq 15 \mathrm{~cm}$ DBH died from age 60 to 75, in low, medium, and high basal area plots, respectively (Fig. 6). In comparison, few $(<25 \%)$ dominant, $\geq 25-\mathrm{cm}$ DBH balsam fir died, except in low density plot 77 , where $43 \%$ of trees $\geq 25 \mathrm{~cm}$ died.

Ryan et al. (1997) analysed potential causes for growth decline in older stands, including: 1) reduced photosynthesis due to increasing hydraulic resistance of tall trees; 2 ) decreasing nutrient supply as a result of nutrient immobilization in living and dead biomass, leading to lower leaf area, a shift in carbon allocation to root production, or reduced photosynthetic capacity; 3) reduced leaf area from abrasion in the crowns of taller trees with longer branches; 4 ) increased mortality of older trees; 5) physiological changes associated with changes in genetic expression; or 6) increased reproductive effort. Ryan et al. (1997) evaluated and then ruled out each of these possible causes, and suggested that a syndrome of changes in structure and function are associated with agerelated growth decline, but that reduced leaf area and photosynthetic capacity appear to be consistent features. However, in the current study, increased mortality of older trees clearly has coincided with and been a major contributing factor to decline.
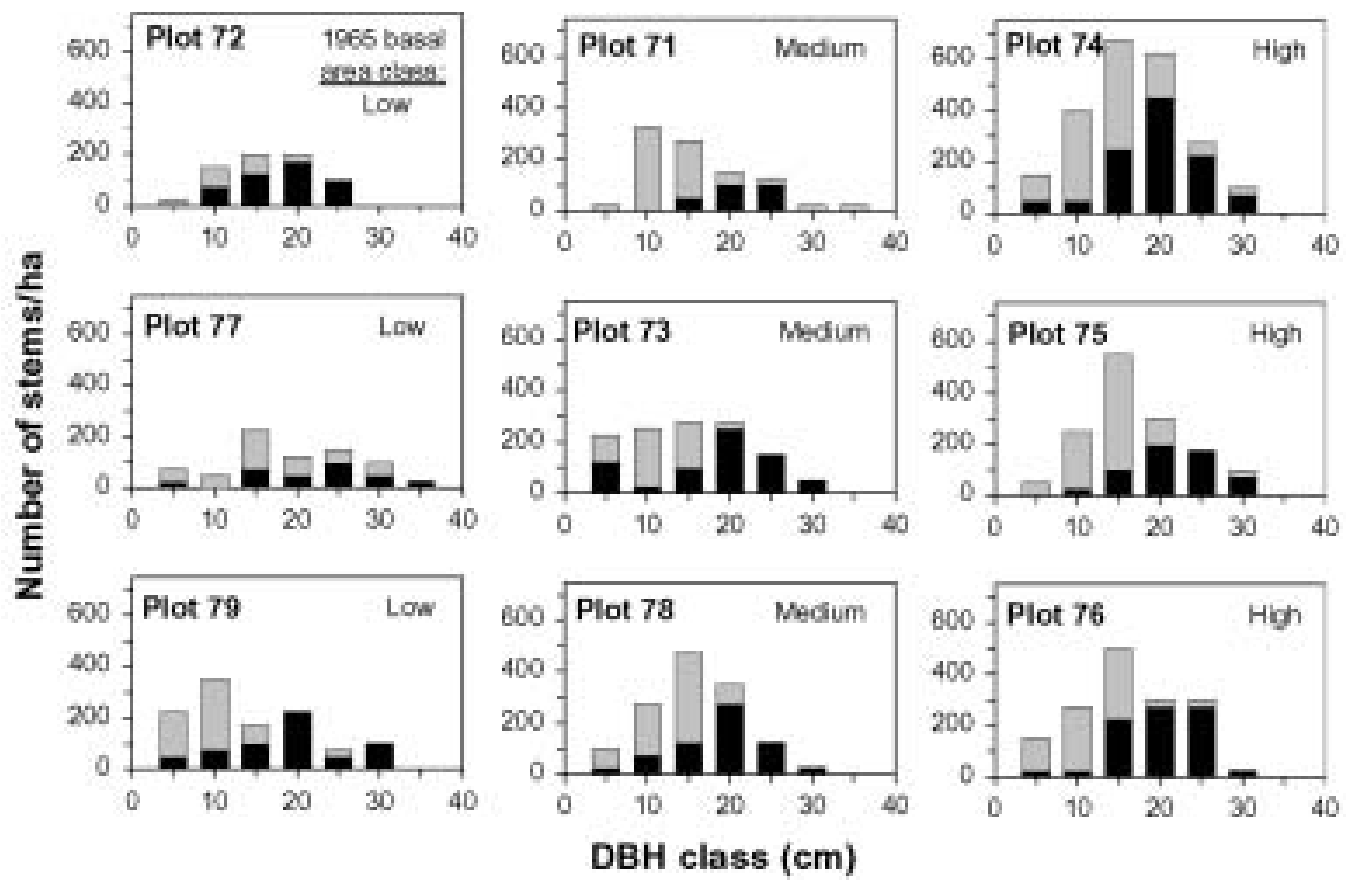

Fig. 6. Diameter distribution (5-cm classes) of living balsam fir trees at age 75 (black) and of trees that died from age 60 to 75 (grey), for nine balsam fir plots in northwestern New Brunswick. Age 45 basal area classes were low ( $\leq 20 \mathrm{~m}^{2} / \mathrm{ha}$ ), medium (21-27 $\mathrm{m}^{2} / \mathrm{ha}$ ), and high $\left(\geq 28 \mathrm{~m}^{2} / \mathrm{ha}\right.$ ) 


\section{Conclusions}

Functionally, spruce budworm has been a pretty good forest manager. When Dr. Gordon L. Baskerville first arrived at Green River (summer 1955), the commercial forest was made up of fir stands, all of budworm origin in outbreaks 40, and 80 , years earlier. The 1950 s outbreak was just beginning. The 80 -year-old stands had survived a "thinning" by a budworm outbreak at age 40, and, at that time were being protected against budworm by insecticide spraying. In short, the fir forest was about half age 40 and half age 80 years, both triggered by previous budworm outbreaks. With insecticide protection in the 1950s and 1970s to 1980s, human harvest patterns gradually changed the forest, instead of an all-at-once killing by budworm, and the insect has lost its role as "periodic manager" of the fir-spruce forest. Indeed, the forest structure is beginning to support all age classes, somewhere, all the time- the classic forest management goal.

This study covers only nine small plots in a single unprotected stand; however, measurements spanning 40 years of stand development, encompassing insect outbreaks and recovery, are so rare they merit attention. Further, decline of older fir-spruce stands has been noted across many permanent plots in New Brunswick (Taylor and MacLean 2005). Differential mortality caused by budworm during the 1950 s resulted in major changes to stand structure. Plots with high, medium, and low residual basal area at age 45 years, following the 1950s outbreak, developed differently over the next 30 years. By age 75, total fir-spruce volume averaged 256, 195, and $130 \mathrm{~m}^{3} /$ ha for high, medium, and low post-outbreak residual basal area plots, respectively. Low residual basal area plots sustained such heavy mortality (64\%-80\%) during the budworm outbreak that they were understocked. In addition to greater total volume, plots with high basal area sustained greater mortality from age 60 to 75 years.

The budworm outbreak in stands aged 35 to 40 years essentially thinned the number of stems by over $50 \%$ in seven plots, resulting in understocked surviving stands. From age 40 to 60 , volume increased rapidly, with low mortality and increasing periodic survivor growth, but after age 60, the stand began to decline. High basal area plots entered the decline or break-up stage earlier than low or medium basal area plots, demonstrating a "legacy effect."

It is not surprising that survivor growth was greater in the high basal area plots; as long as we are evaluating total volume, this should always be the case. It is more surprising that periodic volume increment and diameter increment per stem were also greater. This appears to be because more, larger stems survived in the high basal area plots (Fig. 6). Erdle and MacLean (1999) also noted that dominant stems survived better. Although normally one would think that trees in the high basal area plots would endure more competition, perhaps the 1950s budworm outbreak "thinned" the stand enough to prevent this. Local variations in impact of the 1951 to 1957 spruce budworm outbreak, at age 35 to 40 years, has largely driven stand development over a period that far exceeded the actual defoliation period. Development patterns from age 65 to 75 years were more strongly affected by age 45 (1965, post-budworm outbreak) stand structure than by defoliation in a second 1975 to 1988 (age 55 to 68 years) budworm outbreak, when periodic insecticide application effectively limited mortality.
There are several take-home messages for forest management in this study. First, beware of empirical site index measurements in stands affected by budworm, because unprotected trees can be up to $3 \mathrm{~m}$ to $4 \mathrm{~m}$ shorter following height growth reduction and top-killing (Fig. 1). Second, budworm is undoubtedly a "super silviculturalist" (Baskerville 1975), but its "thinning" does not promote volume production. Mature stands are killed outright, and immature stands end up patchy and understocked. Some people advocate letting budworm "thin" over-dense immature fir, but the resulting stand structure will be a far cry from that of a precommercially spaced stand in terms of timber production, and in spite of good individual tree recovery, it will never catch up to undefoliated stands. Third, effective balsam fir management really needs some insecticide protection, even if only for a few years at the peak of the outbreak, in order to keep growing stock alive. Targeted insecticide protection during the $1950 \mathrm{~s}$ budworm outbreak in this study, which today would use the biological insecticide Bacillus thuringiensis (B.t.), could have prevented the high mortality that resulted in understocked stands.

\section{Acknowledgements}

The Green River K-2 plots were originally established and measured up to 1975 by Dr. Gordon L. Baskerville, and it was his interest and encouragement that resulted in their continued measurement to 1995 . We invited Dr. Baskerville to be a co-author on this paper, but he preferred not to. We gratefully acknowledge all of Dr. Baskerville's contributions to the study and to forestry in Canada! We also acknowledge the Canadian Forest Service, former employer of both Baskerville and MacLean, for funding plot establishment and remeasurements.

\section{References}

Bakuzis, E.V. and H.L. Hansen. 1965. Balsam fir (Abies balsamea (L.) Mill.): a monographic review. University of Minnesota Press, Minneapolis. $445 \mathrm{p}$.

Baskerville, G.L. 1960. Mortality in immature fir following severe budworm defoliation. For. Chron. 36: 342-345.

Baskerville, G.L. 1965. Dry-matter production in immature balsam fir stands. For. Sci. Monogr. 9: 1-42.

Baskerville, G.L. 1975. Spruce budworm: super silviculturalist. For. Chron. 51: 138-140.

Baskerville, G.L. and D.A. MacLean. 1979. Budworm-caused mortality and 20-year recovery in immature balsam fir stands. Can. For. Serv., Marit. For. Res. Cent., Fredericton, NB, Canada. Inf. Rep. M-X-102.

Erdle, T.A. and D.A. MacLean. 1999. Stand growth model calibration for use in forest pest impact assessment. For. Chron. 75: 141-152.

Honer, T.G., M.F. Ker and I.S. Alemdag. 1983. Metric timber tables for the commercial tree species of central and eastern Canada. Can. For. Serv., Marit. For. Res. Cent., Fredericton, NB, Canada. Inf. Rep. M-X-140.

Kettela, E.G. 1975. Aerial spraying for protection of forests infested by spruce budworm. For. Chron. 51: 141-142.

Kettela, E.G. 1983. A cartographic history of spruce budworm defoliation 1967 to 1981 in eastern North America. Can. For. Serv., Ottawa, ON, Canada. Inf. Rep. DPC-X-14.

MacLean, D.A. 1980. Vulnerability of fir-spruce stands during uncontrolled spruce budworm outbreaks: a review and discussion. For. Chron. 56: 213-221.

MacLean, D.A. 1985. Effects of spruce budworm outbreaks on forest growth and yield. In C.J. Sanders, R.W. Stark, E.J. Mullins and J. Murphy (eds.). Recent Advances in Spruce Budworms Research, Proceedings of the CANUSA Spruce Budworms Research 
Symposium, 16-20 Sept. 1984. pp. 148-175. Bangor, Maine. Can. For. Serv., Ottawa, ON, Canada.

MacLean, D.A. 1988. Effects of spruce budworm outbreaks on vegetation, structure, and succession of balsam fir forests on Cape Breton Island, Canada. In M.J.A. Werger, P.J.M. van der Aart, H.J. During and J.T.A. Verhoeven (eds.). Plant Form and Vegetation Structure. pp. 253-261. SPB Academic Publishing, The Hague, The Netherlands.

MacLean, D.A. 1990. Impact of forest pests and fire on stand growth and timber yield: implications for forest management planning. Can. J. For. Res. 20: 391-404.

MacLean, D.A., T.L. Hunt, E.S. Eveleigh and M.G. Morgan. 1996. The relation of balsam fir volume increment to cumulative spruce budworm defoliation. For. Chron. 72: 533-540.

MacLean, D.A., A.W. Kline and D.R. Lavigne. 1984. Effectiveness of spruce budworm spraying in New Brunswick in protecting the spruce component of spruce-fir stands. Can. J. For. Res. 14: 163-176. MacLean, D.A. and W.E. MacKinnon. 1996. The accuracy of aerial sketch mapping of spruce budworm defoliation in New Brunswick. Can. J. For. Res. 26: 2099-2108.

MacLean, D.A. and D.P. Ostaff. 1989. Patterns of balsam fir mortality caused by an uncontrolled spruce budworm outbreak. Can. J. For. Res. 19: 1087-1095.

MacLean, D.A. and H. Piene. 1995. Spatial and temporal patterns of balsam fir mortality in spaced and unspaced stands caused by spruce budworm defoliation. Can. J. For. Res. 25: 902-911.

McLintock, T.F. 1955. How damage to balsam fir develops after a spruce budworm epidemic. U.S. For. Serv., Northeast. For. Exp. Sta., Sta. Pap. No. 75.
Morris, R.F. (ed.). 1963. The dynamics of epidemic spruce budworm populations. Mem. Entomol. Soc. Can. No. 31.

Ostaff, D.P. and D.A. MacLean. 1989. Spruce budworm populations, defoliation, and changes in stand condition during an uncontrolled spruce budworm outbreak on Cape Breton Island, Nova Scotia. Can. J. For. Res. 19: 1077-1086.

Ostaff, D.P. and D.A. MacLean. 1995. Patterns of balsam fir foliar production and growth in relation to defoliation by spruce budworm. Can. J. For. Res. 25: 1128-1136.

Piene, H. 1980. Effects of insect defoliation on growth and foliar nutrients of young balsam fir. For. Sci. 26: 655-673.

Porter, K.B., D.A. MacLean, K.P. Beaton and J. Upshall. 2001. New Brunswick Permanent Sample Plot Database (PSPDB v1.0): user's guide and analysis. Can. For. Serv., Atlantic For. Cent., Fredericton, NB, Canada. Inf. Rep. M-X-209. 65 p.

Ryan, M.G., D. Binkley and J.H. Fownes. 1997. Age-related decline in forest productivity: pattern and process. Adv. Ecol. Res. 27: 213-262.

Sterner, T.E. and A.G. Davidson. 1982. Forest insect and disease condition in Canada, 1981. Can. For. Serv., Ottawa, Ontario, Canada.

Swaine, J.M. and F.C. Craighead. 1924. Studies on the spruce budworm (Cacoecia fumiferana Clem.). Part. 1. A general account of the outbreaks, injury, and associated insects. Can. Dep. Agric., Ottawa, ON, Canada. Tech. Bull. No. 37.

Taylor, S.L. and D.A. MacLean. 2005. Rate of decline of mature and overmature softwood stands by ecological region in New Brunswick. Can. J. For. Res. 35: 2479-2490.

Webb, F.E. and H.J. Irving. 1983. My fir lady - the New Brunswick production with its facts and fancies. For. Chron. 59:118-122. 